\title{
Complex Biomineralization Pathways of the Belemnite Rostrum Cause Biased Paleotemperature Estimates
}

\author{
René Hoffmann ${ }^{1, *(\mathbb{D}}$, Benjamin J. Linzmeier $\left.{ }^{2,3}{ }^{(}\right)$, Kouki Kitajima $\left.{ }^{3} \mathbb{(}\right)$, Gernot Nehrke ${ }^{4}$, Martin Dietzel ${ }^{5} \mathbb{D}$, \\ Niels Jöns ${ }^{1}$ (D), Kevin Stevens ${ }^{1}$ (D) and Adrian Immenhauser ${ }^{1}$ (D) \\ 1 Institut für Geologie, Mineralogie und Geophysik, Ruhr-Universität Bochum, 44801 Bochum, Germany; \\ Niels.Joens@ruhr-uni-bochum.de (N.J.); Kevin.Stevens@rub.de (K.S.); adrian.immenhauser@rub.de (A.I.) \\ 2 Department of Earth Sciences, University of South Alabama, Mobile, AL 36688, USA; blinzmeier@wisc.edu \\ 3 Department of Geoscience, University of Wisconsin-Madison, Madison, WI 53706, USA; \\ saburo@geology.wisc.edu \\ 4 Alfred Wegener Institut Helmholtz-Zentrum für Polar- und Meeresforschung, \\ Section Marine BioGeoSciences, 27570 Bremerhaven, Germany; gernot.nehrke@awi.de \\ 5 Institute of Applied Geosciences, Graz University of Technology, 8010 Graz, Austria; martin.dietzel@tugraz.at \\ * Correspondence: rene.hoffmann@rub.de
}

check for updates

Citation: Hoffmann, R.; Linzmeier, B.J.; Kitajima, K.; Nehrke, G.; Dietzel, M.; Jöns, N.; Stevens, K.; Immenhauser, A. Complex Biomineralization Pathways of the Belemnite Rostrum Cause Biased Paleotemperature Estimates. Minerals 2021, 11, 1406. https://doi.org/ $10.3390 / \min 11121406$

Academic Editor: Alejandro B. Rodriguez-Navarro

Received: 25 August 2021

Accepted: 7 December 2021

Published: 12 December 2021

Publisher's Note: MDPI stays neutral with regard to jurisdictional claims in published maps and institutional affiliations.

Copyright: (c) 2021 by the authors. Licensee MDPI, Basel, Switzerland. This article is an open access article distributed under the terms and conditions of the Creative Commons Attribution (CC BY) license (https:/ / creativecommons.org/licenses/by/ $4.0 /)$.
Abstract: Paleotemperatures based on $\delta^{18} \mathrm{O}$ values derived from belemnites are usually "too cold" compared to other archives and paleoclimate models. This temperature bias represents a significant obstacle in paleoceanographic research. Here we show geochemical evidence that belemnite calcite fibers are composed of two distinct low-Mg calcite phases (CP1, CP2). Phase-specific in situ measurement of $\delta^{18} \mathrm{O}$ values revealed a systematic offset of up to $2 \%$ o $\left(\sim 8{ }^{\circ} \mathrm{C}\right)$, showing a lead-lag signal between both phases in analyses spaced less than $25 \mu \mathrm{m}$ apart and a total fluctuation of $3.9 \%$ \% $\left(\sim 16{ }^{\circ} \mathrm{C}\right)$ within a $2 \mathrm{~cm} \times 2 \mathrm{~cm}$ portion of a Megateuthis (Middle Jurassic) rostrum. We explain this geochemical offset and the lead-lag signal for both phases by the complex biomineralization of the belemnite rostrum. The biologically controlled formation of CP1 is approximating isotope fractionation conditions with ambient seawater to be used for temperature calculation. In contrast, CP2 indicates characteristic non-isotope equilibrium with ambient seawater due to its formation via an amorphous $\mathrm{Ca}-\mathrm{Mg}$ carbonate precursor at high solid-to-liquid ratio, i.e., limited amounts of water were available during its transformation to calcite, thus suggesting lower formation temperatures. CP2 occludes syn vivo the primary pore space left after formation of CP1. Our findings support paleobiological interpretations of belemnites as shelf-dwelling, pelagic predators and call for a reassessment of paleoceanographic reconstructions based on belemnite stable isotope data.

Keywords: paleotemperature reconstruction; belemnites; biomineralization; paleobiology; paleoceanography

\section{Introduction}

Biogenic carbonates have been frequently used as paleoceanographic archives since the development of oxygen isotope analysis [1,2]. The most commonly used biogenic carbonate archives for Mesozoic sea surface temperatures (SST) are planktic foraminifera and mollusks [3].

However, ${ }^{18} \mathrm{O} /{ }^{16} \mathrm{O}$ distribution in calcite is affected by, e.g., seasonal bias [4], growth rate, $\mathrm{Mg}$ content, and amorphous precursor effects (e.g., [5-7]). Vital effects, such as metabolic processes of a biomineralizing organism, differential composition of the precipitating fluid from the bulk environmental fluid, ionic strength (e.g., [8-10]), and secondary diagenetic alteration [11,12], as well as sample averaging [13], all affect paleotemperature estimates.

Belemnite rostra (Figure 1B-E) were initially used in the standardization of carbonate $\delta^{18} \mathrm{O}$ analyses [1] and are considered to be resistant to diagenetic alteration due to their dense low-magnesium calcite composition [14]. However, isotopic variability between rostra from the same stratigraphic horizon and within a single rostrum [10] and the observed 
difference in temperatures calculated between the aragonitic phragmocone and calcitic rostrum of a single specimen [15] question the uncritical applicability of these proxy data for paleoceanographic reconstructions. Large, comparative datasets show conclusively that belemnite rostra deviate towards heavier $\delta^{18} \mathrm{O}$ values compared to other contemporaneous calcitic fauna $[16,17]$. Recent high-resolution petrographic investigation revealed two distinct calcite phases (CP1 and CP2) forming belemnite rostra [18-21]. The timing and mechanism of formation of both phases have important implications for paleoceanographic reconstructions based on bulk analyses. Here we present phase-specific, in situ SIMS $\delta^{18} \mathrm{O}$ values, as well as high-resolution elemental and Raman mappings. Based on these data, we propose a new biomineralization model for belemnite rostra and outline paleoceanographic and paleobiological implications.
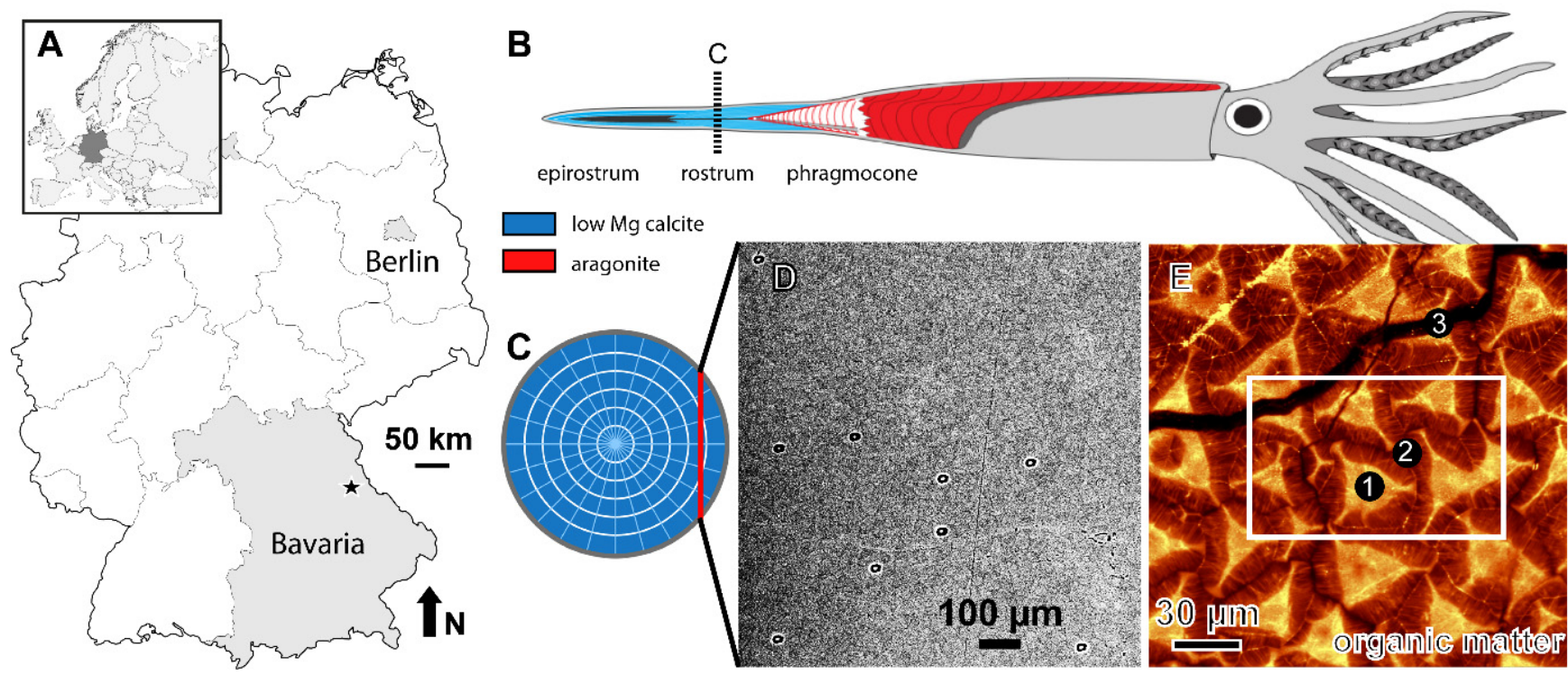
epirostrum rostrum phragmocone
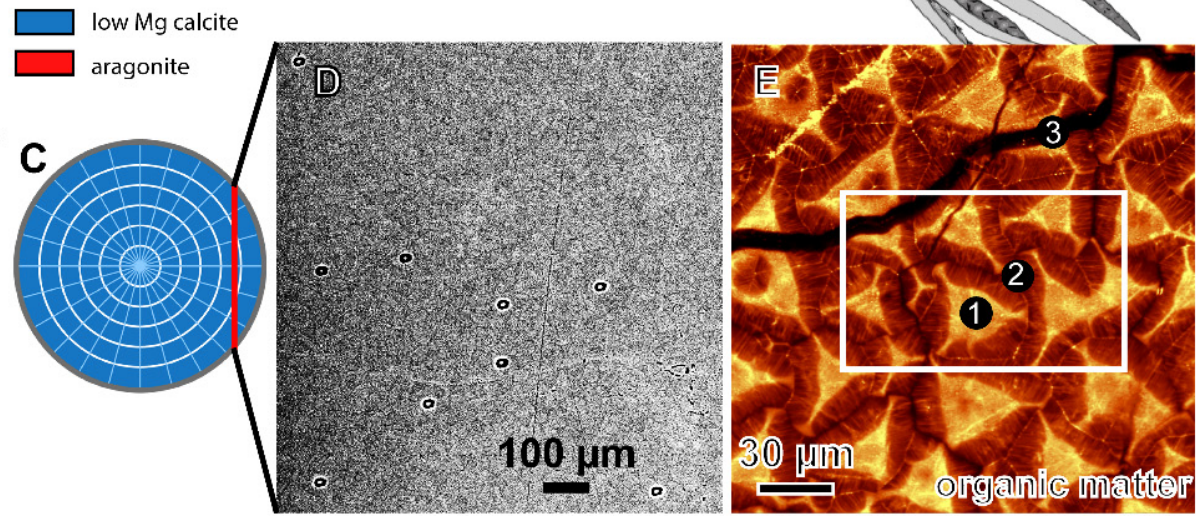

Figure 1. (A) Map of Central Europe and Germany with fossil collection locality (star). (B) Simplified reconstruction of the belemnite animal with its aragonitic phragmocone, calcitic rostrum, and epirostrum (gray, soft tissue). (C) Cross section of the rostrum with radially arranged fibers and growth increments (white). Red line indicates section plane, perpendicular to the calcite fibers, used for analyses resulting in the surface shown in (D). (D) Backscattered electron image of the analyzed polished, thick section surface showing SIMS pits. (E) Raman image (150 $\mu \mathrm{m} \times 150 \mu \mathrm{m}$, resolution $\sim 250 \mathrm{~nm}$ ), showing the background fluorescence distribution, which is indicative for the presence of organic matter within the belemnite rostrum. The trigonal pyramids formed by the first calcite phase $(1, \mathrm{CP} 1)$ are characterized by the highest amount of fluorescence within the Raman spectra, whereas Raman spectra obtained in the second calcite phase (2, CP2) show significantly less fluorescence. The fracture (3) filled with late diagenetic calcite (not further considered) shows no fluorescence in the Raman spectra. The white box refers to the field of view in Figure 2. 

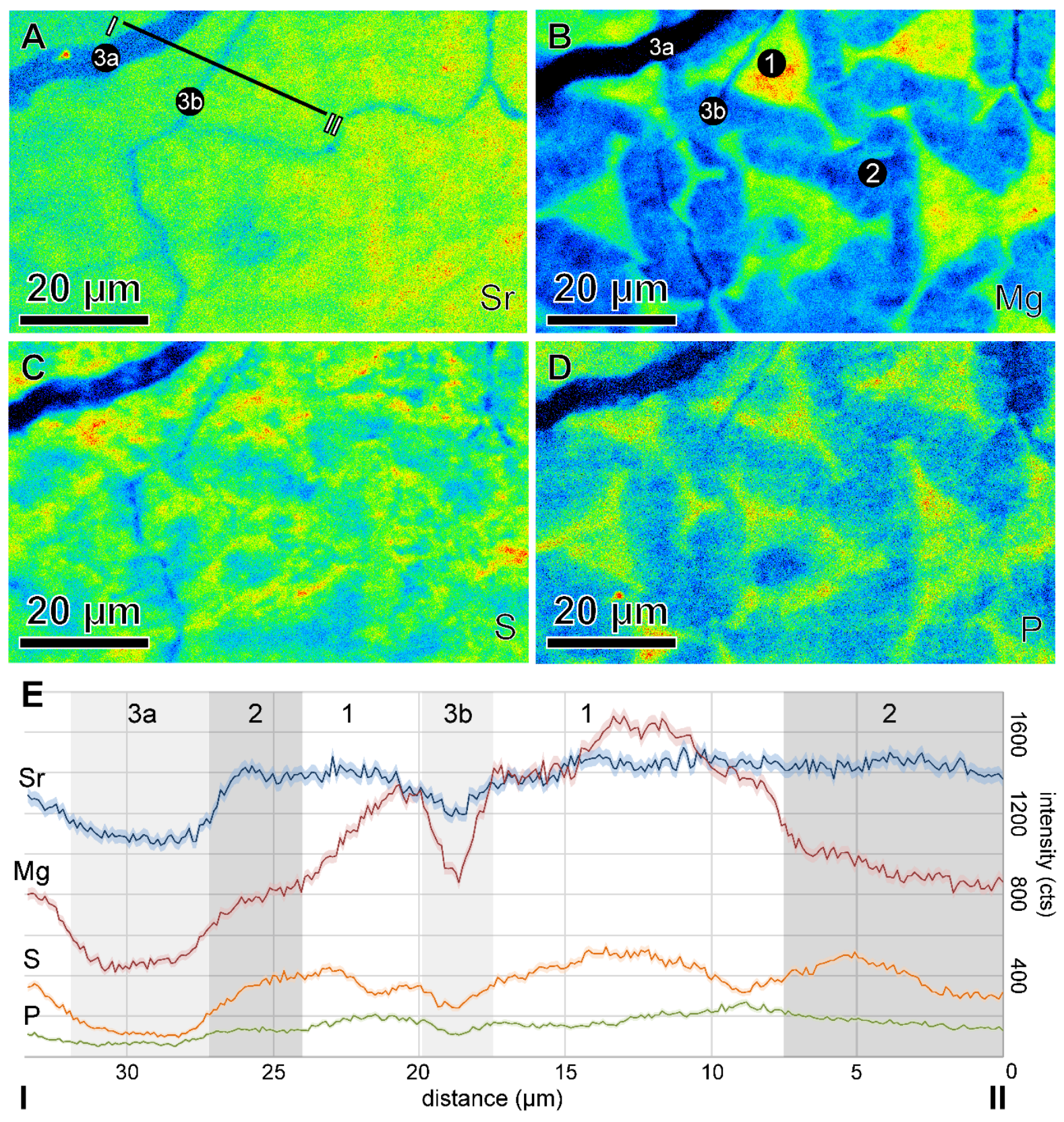

Figure 2. X-ray element distribution maps acquired using electron microprobe (EPMA). (A) Distribution of Sr with slightly higher counts in CP2 and significant lower counts in the late diagenetic calcite (3a and 3b) filling the larger crack. (B) Distribution of $\mathrm{Mg}$ is heterogeneous with higher counts in the biogenic skeleton (CP1) compared to CP2. (C) Counts for $\mathrm{S}$ are similarly distributed as Mg. (D) Distribution of P parallels the pattern Mg. (E) Counts of all four elements along the profile I-II. Note: Bluish colors correspond to lower X-ray intensity, and warmer yellow-red colors, to higher x-ray intensity (numbers in (B) refer to Figure 1 ; confidence bands are given as $1 \sigma$ ).

\section{Materials and Methods}

We used a polished $2 \mathrm{~cm} \times 2-\mathrm{cm}$ section of a Megateuthis rostrum that shows the biphasic microstructure [19]. The specimen comes from the Middle Jurassic of southern Germany (Latitude: 49.4520/Longitude 11.0767, Figure 1A). During deposition, the area was located at about $34^{\circ} \mathrm{N}$ in a warm, fully marine epicontinental sea, about 60 to $80 \mathrm{~km}$ from the coastline, with water depths of up to $70 \mathrm{~m}$ [22].

Electron probe microanalysis (EPMA), confocal Raman microscopy (CRM), backscattered electron microscopy (BSE), and secondary ion mass spectrometry (SIMS) were done on the polished section to investigate differences between CP1 and CP2. EPMA was 
done on a 10-15-nm carbon-coated sample surface using a Cameca SXFiveFE (central microanalytical laboratories, Ruhr-Universität Bochum). For quantitative analysis, we used a defocussed beam ( $5 \mu \mathrm{m}$, acceleration voltage $15 \mathrm{kV}$, probe current $10 \mathrm{nA}$ ), and qualitative $\mathrm{X}$-ray mapping was on a 10-nm-thick gold-coated surface using a focused beam (acceleration voltage $8 \mathrm{kV}$, probe current $400 \mathrm{nA}$ ). CRM was done using a WITec alpha 300 R confocal Raman microscope (Alfred Wegener Institut Helmholtz-Zentrum für Polarund Meeresforschung, Section Marine BioGeoSciences) with an excitation wavelength of $488 \mathrm{~nm}$, a spectrometer grating of $600 / \mathrm{mm}$, and 500-nm blaze. The Cameca IMS-1280 (WiscSIMS, Department of Geoscience, University of Wisconsin) produces high-precision $\left(0.3 \%\right.$, 2SD) analyses of $\delta^{18} \mathrm{O}$ in carbonates with $10-\mu \mathrm{m}$ pit diameter $[23,24]$. Analysis was done using a caesium ion beam with a standard-sample-standard bracketing technique, using two brackets of four analyses of UWC-3 $\left(\delta^{18} \mathrm{O}=-17.87 \%\right.$, Vienna Pee Dee Belemnite, VPDB, [25].

Bulk isotope and thermogravimetric analysis (TGA) were performed on sample powders' averaging areas adjacent to microanalysis drilled using an alumina carbide bit. TGA was done using a Mettler Toledo TGA/DSC 1 (Alfred Wegener Institut HelmholtzZentrum für Polar- und Meeresforschung, Section Marine BioGeoSciences) and a heating rate of $10 \mathrm{k} / \mathrm{min}$. Bulk $\delta^{18} \mathrm{O}$ were measured by gas source mass spectrometry (GSMS) using a Thermo Scientific Delta V Plus isotope ratio mass spectrometer (WiscSIMS, Department of Geoscience, University of Wisconsin) attached to a Thermo Gasbench II/CTC GC-PAL autosampler (WiscSIMS, Department of Geoscience, University of Wisconsin) and a precision of $\pm 0.22 \%$ or for $\delta^{18} \mathrm{O}$.

\section{Results}

Thermogravimetric analysis indicated a weight loss of $1 \%$, similar to water/organic content of speleothem calcite and less than that of modern Porites coral aragonite [26]. The two calcite phases, CP1 and CP2, had distinct isotope and trace element compositions. CRM identified both as calcite and EPMA showed stoichiometric calcite end members $\left(\mathrm{X}_{\mathrm{Cal}}=\mathrm{Ca} /(\mathrm{Ca}+\mathrm{Mg}+\mathrm{Fe}+\mathrm{Mn}+\mathrm{Sr})=0.99\right) . \mathrm{CP} 1$ comprised stacked and interconnected trigonal pyramids with the brightest fluorescence in CRM images (Figure 1E-1), and submicron-size, organic-rich grains. The highest concentrations of $\mathrm{Mg}, \mathrm{P}$, and $\mathrm{S}$ in the EPMA map were within CP1, supporting the interpretation of organic matter from CRM fluorescence $[27,28]$. SIMS $\delta^{18} \mathrm{O}$ values of $\mathrm{CP} 1$ were $-0.5 \%$ o $(\mathrm{VPDB} ; N=49)$ on average, 2SD of $1.8 \%$, and a range from -2.1 to $0.8 \%$ (Figures 3 and 4 ).

Darker areas in the CRM images with isopachous texture were CP2 (Figure 1E-2) [19] and had the highest Sr concentration. CP2 crystallites were oriented perpendicularly to the surface of the trigonal pyramids forming CP1. Thin, organic-rich layers were observed between individual crystals (Figure 1E). SIMS $\delta^{18} \mathrm{O}$ values of CP2 were $+0.3 \%$ (VPDB, $N=39$ ) on average, $2 \mathrm{SD}$ of $1.8 \%$, and a range from -1.3 to $1.7 \%$ (Figures 3 and 4 ).

On average, SIMS analyses of CP2 were $0.8 \%$ higher than CP1. Directly paired analyses measured within a distance of $25 \mu \mathrm{m}$ showed CP2 with an average value of about $+1.0 \%$ o higher than CP1 (number of pairs $=21$, standard error of mean $=0.2, T$-test for no difference $p \leq 0.001$ ). When compared across rostral growth, variation in CP2 lagged that of CP1 by $100 \mu \mathrm{m}$ (Figure 3). Bulk analyses showed an average $\delta^{18} \mathrm{O}$ of $+0.7 \pm 0.2 \%$ o (VPDB). The bulk $\delta^{18} \mathrm{O}$ value, within analytical uncertainty, intersected CP2 $(+0.5 \%$ o $)$. 


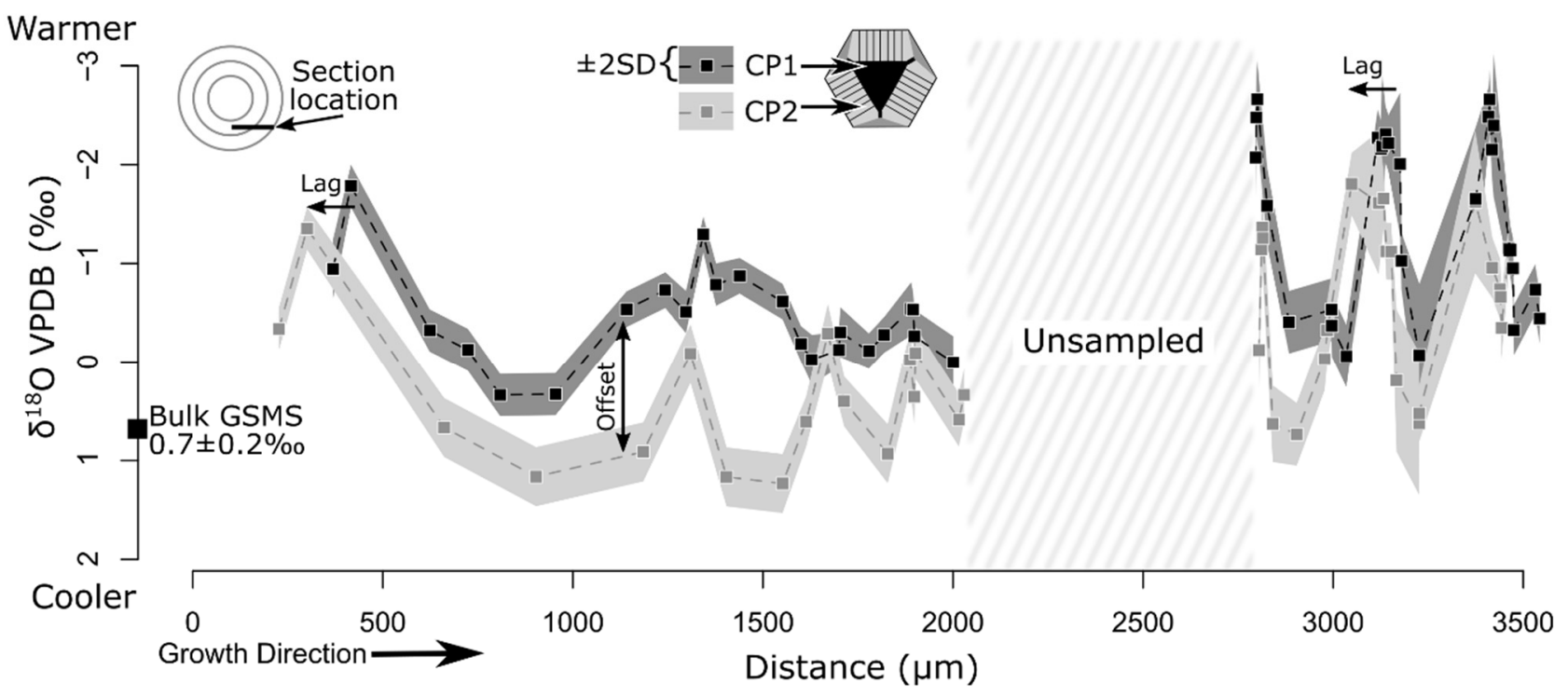

Figure 3. Variation in $\delta^{18} \mathrm{O}$ across the belemnite rostrum. $\mathrm{CP} 1$ generally has lower $\delta^{18} \mathrm{O}$ compared to adjacent $\mathrm{CP} 2$ (mean offset of $0.8 \%$ ). At several points, $\delta^{18} \mathrm{O}$ of $\mathrm{CP} 2$ is lower than that of nearby $\mathrm{CP} 1$, most notably near $3250 \mu \mathrm{m}$. This crossover highlights the lag between sinusoids in $\mathrm{CP} 1$ and $\mathrm{CP} 2$. Growth banding is more closely spaced toward the right of the sampling transect because of the geometry of growth rings related to the cutting plane (Figure 1C and inset in top left corner). A single bulk value using conventional acid digestion gas-source mass spectrometry (GSMS) was sampled in a trench parallel to the SIMS transect for method comparison.

\section{Discussion}

The analyzed rostrum of Megateuthis showed no signs of significant diagenetic alteration [19] using established screening methods (e.g., [11]). It showed an intrinsic bluish luminescence and intact fibrous microfabric, all indicative for well-preserved calcite ([19], Figure 5C,F). A few fractures and microstylolites were avoided during sampling.

\subsection{SIMS Accuracy}

Small differences in minor element chemistry did not significantly influence the accuracy of SIMS-measured $\delta^{18} \mathrm{O}$ values in carbonates [24]. Thermogravimetric analysis analyses revealed a weight loss of $0.4 \%$ between $0-200{ }^{\circ} \mathrm{C}$, attributable to water loss, while weight loss between $200-600^{\circ} \mathrm{C}$ was attributed to the combustion of organic matter [29]. There was a small difference in the amount of organic matter between both calcite phases visualized by CRM (Figure 1E). Small differences in organic matter content within a speleothem [30], Nautilus shell [23], fish otoliths [31], and the rostrum analyzed herein did not bias $\delta^{18} \mathrm{O}$ values measured in organic-rich or organic-lean domains.

\subsection{Oxygen Isotope Fractionation between Calcite and Water: Definitions and Range}

The oxygen isotope fractionation factor between calcite and a precipitating water was defined by the $n$ moles of ${ }^{18} \mathrm{O}$ and ${ }^{16} \mathrm{O}$ of the calcite (cc) divided by the $n$ moles of ${ }^{18} \mathrm{O}$ and ${ }^{16} \mathrm{O}$ of the precipitating water:

$$
\alpha_{\mathrm{cc}-\mathrm{H}_{2} \mathrm{O}}=\frac{{ }^{18} \mathrm{R}_{\mathrm{cc}}}{{ }^{18} \mathrm{R}_{\mathrm{H}_{2} \mathrm{O}}}=\frac{\mathrm{n}_{\mathrm{cc}}\left({ }^{18} \mathrm{O}\right) / \mathrm{n}_{\mathrm{cc}}\left({ }^{16} \mathrm{O}\right)}{\left.\mathrm{n}_{\mathrm{H}_{2} \mathrm{O}} \mathrm{O}{ }^{18} \mathrm{O}\right) / \mathrm{n}_{\mathrm{H}_{2} \mathrm{O}}\left({ }^{16} \mathrm{O}\right)}=\frac{\delta^{18} \mathrm{O}_{\mathrm{cc}}+1000}{\delta^{18} \mathrm{O}_{\mathrm{H}_{2} \mathrm{O}}+1000}
$$

The isotope fractionation factor, $\alpha_{\mathrm{cc}-\mathrm{H}_{2} \mathrm{O}}$, which was closest to isotope equilibrium conditions, was estimated by speleothem calcite grown at extreme low precipitation rates (see [32,33]). Kinetically driven oxygen isotope fractionation effects can be related to non-isotopically equilibrated dissolved inorganic carbonate (DIC) species and/or high precipitation rates (e.g., [5,34-36]). Both effects are known to result in lower apparent $\alpha_{\mathrm{cc}-\mathrm{H}_{2} \mathrm{O}}$ values compared to equilibrium conditions. In brief, these kinetic effects were re- 
flecting isotopic disequilibrium conditions between the aqueous DIC species, e.g., induced by $\mathrm{pH}$ change or $\mathrm{CO}_{2}$ degassing and/or during the uptake of the aqueous carbonate at the growing calcite surface (e.g., $[5,35,37])$. In this context, the temperature-dependent $\alpha_{\mathrm{cc}-\mathrm{H}_{2} \mathrm{O}}$ relationship of Kim and $\mathrm{O}^{\prime} \mathrm{Neil}$ [38] is most frequently used as calibration equation, which indeed represents out-of-isotope equilibrium conditions (about 1.5\% to 2\% lower

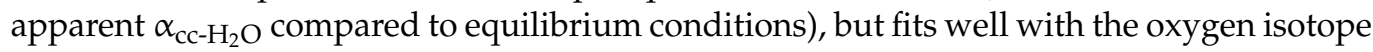
fractionation behavior during most common calcite formation conditions at the surface of the Earth, approximating isotope fractionation conditions at low precipitation rates (see $[5,32,39])$. In contrast, higher apparent $\alpha_{\mathrm{cc}-\mathrm{H}_{2} \mathrm{O}}$ values compared to equilibrium conditions were documented for calcite formed via amorphous $\mathrm{Ca}-\mathrm{Mg}$ carbonate precursors, in particular, expected at high solid-to-liquid ratio, i.e., limited water availability during the transformation [7].

\subsection{Oxygen Isotope Differences in the Two Calcite Phases}

CP1 represented the phase formed under strict biological control [19] and was less affected by common kinetically driven oxygen isotope effects due to the presence of carbonic anhydrase (CA) enzyme [40], whose presence was inferred based on the presence of CA in modern mollusks including cephalopods [41-43]. Estimated formation temperature of CP1 calcite from $\delta^{18} \mathrm{O}_{\mathrm{cc} \_\mathrm{CP} 1}$ values, according to Kim and $\mathrm{O}^{\prime} \mathrm{Neil}$ [38], yielded $12 \pm 4{ }^{\circ} \mathrm{C}$, which indicated a high scatter of temperatures derived from a single rostrum. Oxygen isotope distribution of secondary $\mathrm{CP} 2$ calcite, in only about $25-\mu \mathrm{m}$ distance from $\mathrm{CP} 1$ calcite, exhibited significantly lower $\delta^{18} \mathrm{O}_{\mathrm{cc} \_} \mathrm{CP} 2$ values (max. delta: $-2.5 \%$; Figure $4 \mathrm{~A}$ with deviation of $\mathrm{CP} 1$ und $\mathrm{CP} 2$ temperatures up to $\sim 8{ }^{\circ} \mathrm{C}$ ), which cannot reasonably be explained by varying environmental formation temperatures. Accordingly, the local change in $\delta^{18} \mathrm{O}$ values is, rather, suggested to be based on calcite formation pathways. The potential impact on the $10^{3} \ln \left(\alpha_{\mathrm{cc}-\mathrm{H}_{2} \mathrm{O}}\right)$ value was displayed by setting the calculated $\mathrm{T}_{\mathrm{CP} 1}$ as references $\left(\mathrm{T}_{\mathrm{CP} 1}=\mathrm{T}_{\mathrm{CP} 2}\right.$; Figure $\left.4 \mathrm{~B}\right)$. In the present case of biogenically induced formation, the higher apparent $10^{3} \ln \left(\alpha_{\mathrm{cc}-\mathrm{H}_{2} \mathrm{O}}\right)$ values of $\mathrm{CP} 2$ versus $\mathrm{CP} 1$ in Figure $4 \mathrm{~B}$ cannot be explained by reaching isotope equilibrium conditions such as those documented in speleothems (see [33]). In contrast, the apparent $10^{3} \ln \left(\alpha_{\mathrm{cc}-\mathrm{H}_{2} \mathrm{O}}\right)$ of $\mathrm{CP} 2$ hinted towards the formation of calcite via an amorphous carbonate precursor and its transformation within a waterlimited environment, thus still reflecting the preferential entrapment of the ${ }^{18} \mathrm{O}$ (versus ${ }^{16} \mathrm{O}$ ) during amorphous carbonate formation in the final calcite. Thus, CP2 is suggested to be precipitated out of isotope equilibrium with seawater, reflecting an isotope fractionation behavior typical for amorphous pathway of calcite formation. In analogy to CP2, the oxygen isotope fractionation between carbonated hydroxyapatite (CHAP: synthesized between 6 to $80^{\circ} \mathrm{C}$; [44]) and water indicated a temperature dependence of $\delta^{18} \mathrm{O}_{\text {carbonate }}$ close to the relationship of Daëron et al. [33]. This further supports our above-developed concept of CP2 formation strategy, as CHAP precipitates are known to be formed through an amorphous precursor stage.

Alternatively, reduction of CA due to less exposed enzyme-hosting organic membranes or differing secretion rates could limit $\mathrm{CO}_{2}-\mathrm{H}_{2} \mathrm{O}$ system equilibration [43]. Vital effects in mollusks generally cause lower $\delta^{18} \mathrm{O}$ values and, therefore, cannot explain the observed offset ([45,46], but see [47]). Disequilibrium formation of CP2 and equilibrium secretion of $\mathrm{CP} 1$ provide a plausible explanation for the observed $\delta^{18} \mathrm{O}$ offset and represent a biomineralization chronology. 

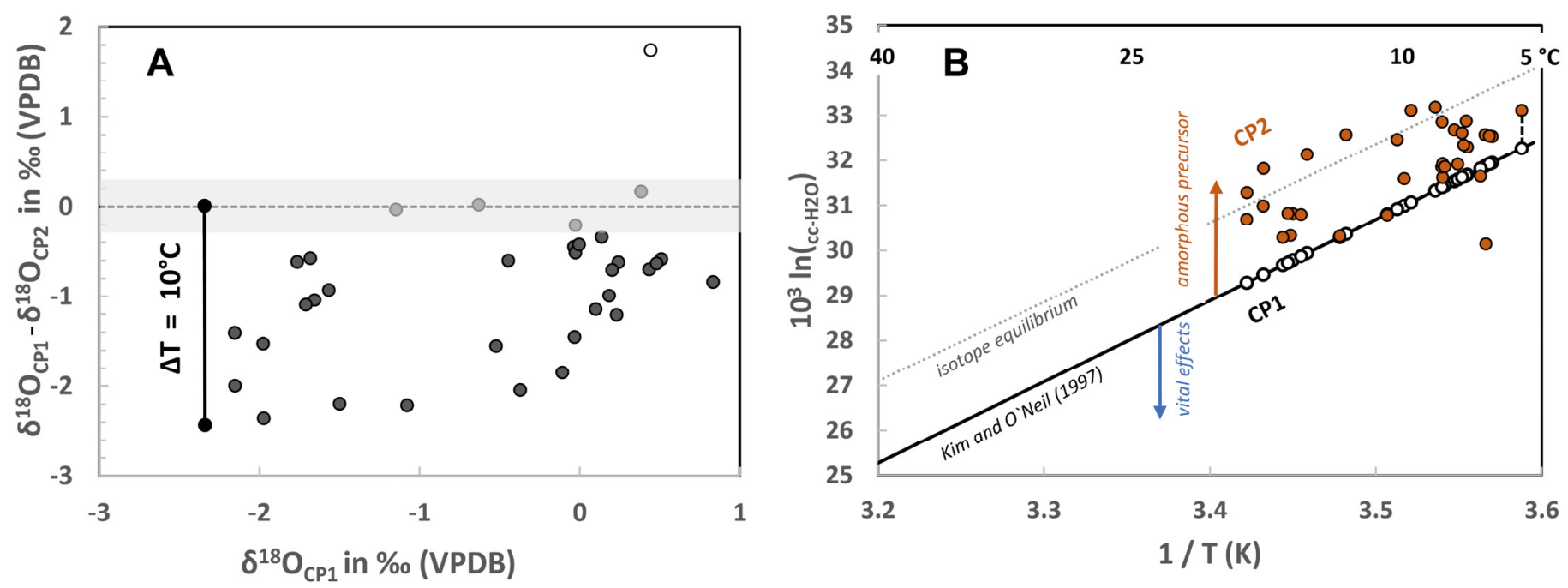

Figure 4. (A) Difference between the oxygen isotope composition of $\mathrm{CP} 1$ and $\mathrm{CP} 2$ calcite $\left({ }^{18} \mathrm{O}_{\mathrm{CP} 1-} \delta^{18} \mathrm{O}_{\mathrm{CP} 2}\right.$ in $\%$ ) from spot analyses within a $25-\mu \mathrm{m}$ distance from each other. CP2 is isotopically heavier than CP1 calcite, except two cases showing identical CP2 and CP1 values within the analytical precision (shaded area) and one case with a contrary behavior. (B) Oxygen isotope fractionation between calcite (cc) and water $\left(10^{3} \ln \left(\alpha_{\mathrm{cc}-\mathrm{H}_{2} \mathrm{O}}\right)\right)$ as a function of temperature ( $\mathrm{T}$ in $\left.\mathrm{K}\right)$. $\bigcirc$ and $\bullet$ : data for CP1 and CP2 calcite, where $\alpha_{\mathrm{cc}-\mathrm{H}_{2} \mathrm{O}}=\left(\delta^{18} \mathrm{O}_{\mathrm{CPi}}+1000\right) /\left(\delta^{18} \mathrm{O}_{\mathrm{H}_{2} \mathrm{O}}+1000\right)(\mathrm{i}=1$, 2 ; see values in Table S1) are estimated by considering Mesozoic seawater to be $\delta^{18} \mathrm{O}_{\mathrm{H}_{2} \mathrm{O}}(\mathrm{SMOW}) \approx-1.0 \%$ (equal to $-30.95 \%$, VPDB) at ice-free condition [48]. Black, solid line is obtained from inorganic calcite precipitation experiments at low precipitation rates [38] and is used as a $\mathrm{T}_{\mathrm{CP} 1}$ calibration line for $\mathrm{CP} 1$ calcite, representing a baseline for biogenically induced calcite. $\mathrm{CP} 2$ calcites are plotted vs. $\mathrm{T}_{\mathrm{CP} 1}$ values, assuming identical formation temperatures for $\mathrm{CP} 1$ and $\mathrm{CP} 2$, to follow the shift of oxygen isotope fractionation from $\mathrm{CP} 1$ to $\mathrm{CP} 2$, suppressing $\mathrm{T}$ effects (exemplarily indicated by the dashed line at about $6{ }^{\circ} \mathrm{C}$ ). Dotted line: oxygen isotope equilibrium conditions, as proposed by Daëron et al. [33], from calcitic speleothems. Blue arrow: trend of increasing impact of vital effects on calcite precipitation (including precipitation rate and DIC disequilibrium effect (e.g., [5])). Red arrow: trend of increasing impact of calcite formed via amorphous Ca-Mg carbonate precursors at high solid-to-liquid ratio, i.e., water is limited during the transformation [7].

\subsection{Rostrum Biomineralization Model}

Secretion of organic scaffolds from mantle cells controls the shape and growth rate of the rostrum (Figure 1B,C; [49]). In the rostrum, membranes with equidistant spacing lie parallel to the growth surface confining an extrapallial fluid reservoir (domain a, Figure 5E) that is compositionally derived from ambient seawater. Organic scaffolds between these membranes serve as sites for secretion and control the shape and crystallographic orientation of CP1 trigonal pyramids [19].

At first, CP1 started to form a filigree framework of organic-rich calcite trigonal pyramids. A second membrane-scaffold-membrane layer was constructed as the first layer of CP1 was secreted. Residual water in the cavity, where the first layer of CP1 was secreted, likely was altered from its original composition by removal of $\mathrm{CO}_{3}{ }^{2-}$ and $\mathrm{Ca}^{2+}$. With a lag of about two growth layers $(\sim 100 \mu \mathrm{m}), C P 1$ secreted in the second layer, contemporaneously with CP2 growing syn vivo in the remaining pore space within the first layer.

This model explains both the similarity in the magnitude of $\delta^{18} \mathrm{O}$ variation within CP1 and CP2 and their spatial lag (Figure 3). Oxygen isotope values of CP2 had higher $\delta^{18} \mathrm{O}$ (on average $\sim 0.8 \%$ ) compared to those of CP1 but displayed a similar amount of variability and a sinusoidal pattern. A potential argument for an amorphous precursor forming CP2 is the assumed less water present during transformation to calcite, which results in a larger big delta value. Given the dependence on the organic scaffold, CP1 formed under biological control in the presence of CA (sensu [49]), thus reflecting the isotope fractionation relationship of $\mathrm{Kim}$ and $\mathrm{O}^{\prime} \mathrm{Neill}$ [38]. Isopachous CP2 calcite crystals nucleated on the surface of the trigonal pyramids without organic scaffolds, but most likely through an amorphous precursor (Figures 1E and 5; [50]). Additional research on 
the nanometer scale could provide proof for the presence or absence of an alternating layered structure resulting from the decomposition of the amorphous precursor phase, as was recently demonstrated by [51,52]. Extra-crystalline organic matrix or residual organic matter in the calcifying fluid was trapped along the surfaces of the CP2 crystals (Figure 1E). Other potentially biologically induced biominerals are known from sepiid cuttlebones [53] and from intercameral deposits of some fossil cephalopods [54,55].

Similar findings of microstructural complexity were described for five Middle Jurassic to Late Cretaceous belemnite genera [18,31], which suggests that this specific type of rostrum microstructure and biomineralization pathway is universally present in belemnites. Interestingly, layers of organic membranes running parallel to the mineralized septa of the Sepia cuttlebone have a similar spatial arrangement and may help to better visualize the formation process of the belemnite rostrum microstructure (Figure 5).

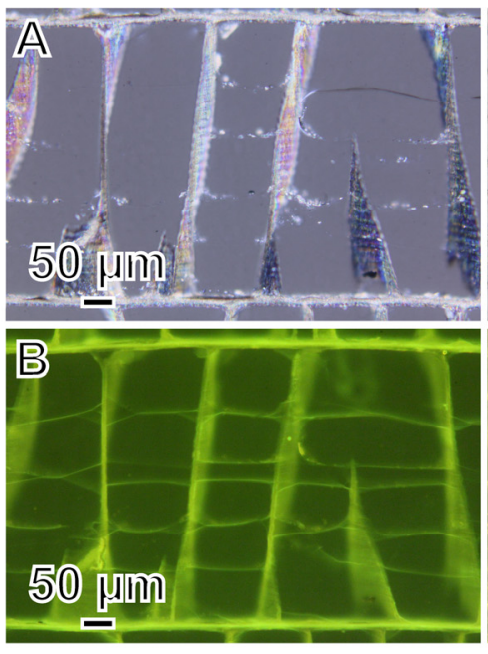

Sepia, cuttlebone

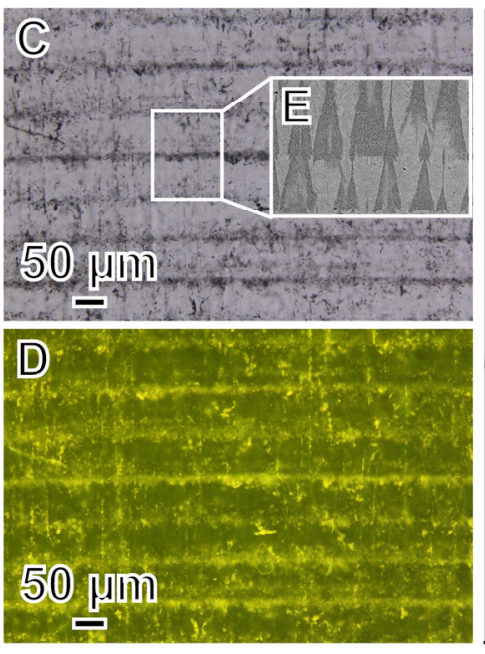

Megateuthis, rostrum

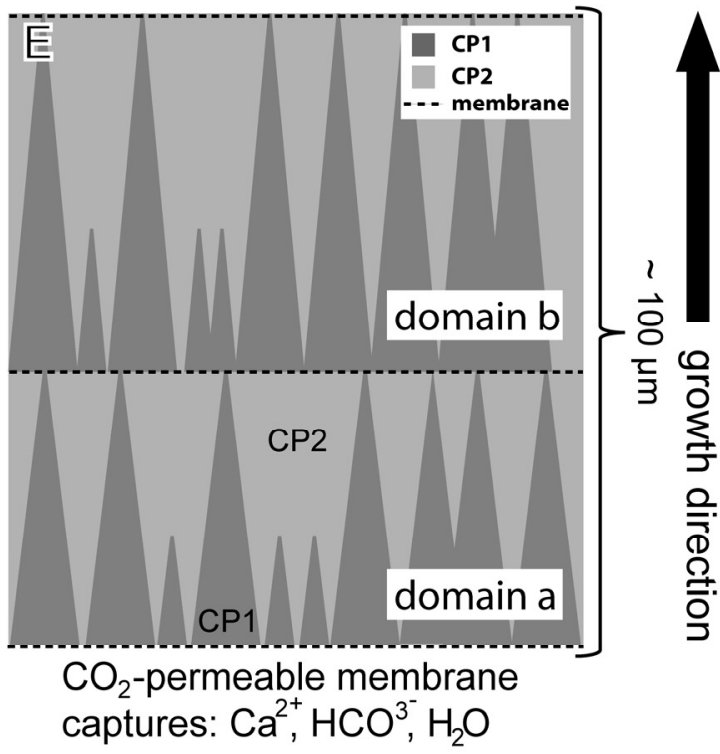

Figure 5. Precipitation model for the belemnite rostrum. (A,B) Sepia officinalis cuttlebone seen under (A) polarized light with a small scale banding of the pillars and (B) under the fluorescence microscope with membranes associated with growth bands [56]. (C,D) Cross section of a Megateuthis rostrum showing, at comparable scales, organic-rich layers, representing former organic membranes under (C) transmitted light and (D) under the fluorescence microscope; white box in C shows a BSE image [19] of trigonal pyramids (CP1), as depicted in the model (E), with slightly variable distances between each layer. (E) Scheme of calcite phases in cross-section view showing the growth model: 1, two organic membranes form a delineated space; carbonic anhydrase is associated with these membranes; 2, CP1 in domain a precipitates with its trigonal pyramid morphology determined by organic framework; 3 , forming of an organic framework and isolating membrane for $\mathrm{CP} 1$ in domain b; 4, CP1 in domain b precipitates simultaneously with CP2 of domain a. The process repeats with continued organic matter scaffolding growth (see Supplementary for additional information).

\subsection{Paleoceanographic Implications}

The complex intergrowth of $\mathrm{CP} 1$ and $\mathrm{CP} 2$ means bulk $\delta^{18} \mathrm{O}$ values likely bias reconstructions toward colder temperatures. The lowest $\delta^{18} \mathrm{O}$ values in $\mathrm{CP} 1(-2.7 \%)$ might be the best representation of maximum SST because they produced the highest temperature estimates [31]. The homogenized bulk $\delta^{18} \mathrm{O}$ value for this sample was $+1.2 \%$ higher than average values of $\mathrm{CP} 1$ and biased temperature estimates to colder temperatures by $\sim 5^{\circ} \mathrm{C}$ [38]. We suggest correction for this bias should be done with additional petrographic and in situ geochemical sampling and not extrapolation from a single rostrum. We hypothesized that species-specific and intraspecific differences in the proportion of $\mathrm{CP} 1$ to $\mathrm{CP} 2$ as well as differences in the magnitude of $\delta^{18} \mathrm{O}$ offset between $\mathrm{CP} 1$ and $\mathrm{CP} 2$ exist. There is limited indication for clumped isotope close to equilibrium formation of belemnite calcite based on the dual clumped isotope $\left(\Delta_{47}, \Delta_{48}\right)$ analysis of a single rostrum [57]. However, 
non-equilibrium $\delta^{18} \mathrm{O}$ values would preclude a straightforward reconstruction of past $\delta^{18} \mathrm{O}$ seawater composition based on clumped isotope temperatures [58].

\subsection{Belemnite Paleobiology}

Paleobiological evidence of belemnite lifestyle (e.g., comparative morphology, taphonomy) suggests they were mobile, active swimmers, and our new data fit into this framework [59]. Sinusoidal $\delta^{18} \mathrm{O}$ variation can be explained by vertical migration and/or seasonal temperature variability [13]. An interpretation of $\delta^{18} \mathrm{O}$ as solely seasonal, however, is unlikely because it would suggest a long ( $>5$ years) lifespan at fixed depth for Megateuthis, while modern, shallow-water coleoids, which are ecologically comparable to belemnites, have lifespans of 1-2 years [60]. Vertical migration through a stratified water column multiple times could produce the measured $\delta^{18} \mathrm{O}$ pattern (Figure 3; [23]) but such gradients in temperature or $\delta^{18} \mathrm{O}$ of the seawater would have been present in the top $200 \mathrm{~m}$ of the water column due to mechanical limitations of belemnite shells [59].

\section{Conclusions}

We demonstrated that well-preserved belemnite rostra have heterogeneous $\delta^{18} \mathrm{O}$ values on a scale of $25 \mu \mathrm{m}$. Belemnite rostra record a complex, phase-specific oxygen isotope pattern, suggesting the first calcite phase $(\mathrm{CP} 1)$ to be reflecting formation temperature and a second calcite phase (CP2) formed via amorphous precursor, which induces a typical enrichment of ${ }^{18} \mathrm{O}$ vs. ${ }^{16} \mathrm{O}$ in the precipitating carbonate. Bulk data, comprising both calcite phases, likely bias paleotemperature estimates by $\sim 2-4{ }^{\circ} \mathrm{C}$ towards colder temperatures. Therefore, reliable paleotemperature estimates can only be reconstructed from in situ sampled CP1. The observed offset in $\delta^{18} \mathrm{O}$ values of $\mathrm{CP} 1$ and $\mathrm{CP} 2$ can be best explained by biomineralization of $\mathrm{CP} 1$ from extrapallial fluid derived from seawater most likely in the presence of carbon anhydrase and the formation of CP2 from the transformation of an amorphous calcium carbonate precursor under a high solid/liquid ratio. The lead-lag in the formation of both phases implies that the rostra are initially less dense than pure calcite but increase in density during growth of the belemnite rostrum. Future petrographic and in situ geochemical sampling will provide constraints on the apparent bias in bulk records and, therefore, can help to refine our understanding of paleoceanography throughout the Jurassic, Cretaceous, and belemnite paleobiology.

Supplementary Materials: The following are available online at https://www.mdpi.com/article/ 10.3390/min11121406/s1: Figure S1: Thermogravimetric analyses of different carbonate materials. Figure S2: Classification of SIMS pits and associated 818 Obelemnite. Figure S3: Detailed precipitation model for calcitic belemnite rostra. Table S1: Summary statistics for the pit category data and related oxygen isotope ratios.

Author Contributions: Conceptualization, R.H. and B.J.L.; methodology, R.H. and B.J.L.; formal analysis, N.J., M.D., K.K. and B.J.L.; investigation, all; resources, R.H.; data curation, N.J. and B.J.L.; writing—original draft preparation, R.H. and B.J.L.; writing—review and editing, R.H., B.J.L., K.K., G.N., M.D., N.J., K.S. and A.I. All authors have read and agreed to the published version of the manuscript.

Funding: This research received no external funding.

Data Availability Statement: Data supporting reported results can be found in the Supplementary Materials and external data table, (S1 EMPA external data table: https:/ /www.dropbox.com/s/0ciu9mo3lftwl9 0/S1\%20EMPA\%20external\%20data\%20table.xlsx?dl=0) and (S2 SIMS external data table: https: //www.dropbox.com/s/93fjarsl2ostpne/S2\%20SIMS\%20external\%20data\%20table.xlsx?dl=0).

Acknowledgments: WiscSIMS is supported by (EAR13-55590) and the University of WisconsinMadison. We received support from T. Puettmann for creating Figure 1A,B. R.H. acknowledges fruitful discussions with F. Wiese and D. Fuchs and the help of P. Mono for the formatting.

Conflicts of Interest: The authors declare no conflict of interest. 


\section{References}

1. Urey, H.C.; Lowenstam, H.A.; Epstein, S.; McKinney, C.R. Measurement of paleotemperatures and temperatures of the Upper Cretaceous of England, Denmark, and the Southeastern United States. GSA Bull. 1951, 62, 399-416. [CrossRef]

2. McCrea, J.M. On the isotopic chemistry of carbonates and a paleotemperature scale. J. Chem. Phys. 1950, 18, 849-857. [CrossRef]

3. O'Brien, C.L.; Robinson, S.A.; Pancost, R.D.; Sinninghe Damsté, J.S.; Schouten, S.; Lunt, D.J.; Alsenz, H.; Bornemann, A.; Bottini, C.; Brassell, S.C.; et al. Cretaceous sea-surface temperature evolution: Constraints from TEX 86 and planktonic foraminiferal oxygen isotopes. Earth Sci. Rev. 2017, 172, 224-247. [CrossRef]

4. Ivany, L.C. Reconstructing Paleoseasonality from Accretionary Skeletal Carbonates-Challenges and Opportunities. Paleontol. Soc. Pap. 2012, 18, 133-165. [CrossRef]

5. Dietzel, M.; Tang, J.; Leis, A.; Köhler, S.J. Oxygen isotopic fractionation during inorganic calcite precipitation-Effects of temperature, precipitation rate and pH. Chem. Geol. 2009, 268, 107-115. [CrossRef]

6. Mavromatis, V.; Schmidt, M.; Botz, R.; Comas-Bru, L.; Oelkers, E.H. Experimental quantification of the effect of Mg on calciteaqueous fluid oxygen isotope fractionation. Chem. Geol. 2012, 310-311, 97-105. [CrossRef]

7. Dietzel, M.; Purgstaller, B.; Kluge, T.; Leis, A.; Mavromatis, V. Oxygen and clumped isotope fractionation during the formation of $\mathrm{Mg}$ calcite via an amorphous precursor. Geochim. Cosmochim. Acta 2020, 276, 258-273. [CrossRef]

8. Spero, H.J.; Lea, D.W. Experimental determination of stable isotope variability in Globigerina bulloides: Implications for paleoceanographic reconstructions. Mar. Micropaleontol. 1996, 28, 231-246. [CrossRef]

9. Owen, R.; Kennedy, H.; Richardson, C. Isotopic partitioning between scallop shell calcite and seawater: Effect of shell growth rate. Geochim. Cosmochim. Acta 2002, 10, 1727-1737. [CrossRef]

10. Stevens, K.; Griesshaber, E.; Schmahl, W.; Casella, L.A.; Iba, Y.; Mutterlose, J. Belemnite biomineralization, development, and geochemistry: The complex rostrum of Neohibolites minimus. Palaeogeogr. Palaeoclimatol. Palaeoecol. 2017, 468, 388-402. [CrossRef]

11. Ullmann, C.V.; Korte, C. Diagenetic alteration in low-Mg calcite from macrofossils: A review. Geol. Q. 2015, 59, 3-20. [CrossRef]

12. Immenhauser, A.; Schöne, B.R.; Hoffmann, R.; Niedermayr, A. Mollusc and brachiopod skeletal hard parts: Intricate archives of their marine environment. Sedimentology 2016, 63, 1-59. [CrossRef]

13. Linzmeier, B.J. Refining the interpretation of oxygen isotope variability in free-swimming organisms. Swiss J. Palaeontol. 2019, 138, 109-121. [CrossRef]

14. Sælen, G. Diagenesis and construction of the belemnite rostrum. Palaeontology 1989, 32, 765-798.

15. Price, G.D.; Hart, M.B.; Wilby, P.R.; Page, K.N. Isotopic analysis of Jurassic (Callovian) mollusks from the Christian Malford Lagerstätte (UK): Implications for ocean water temperature estimates based on belemnoids. PALAIOS 2015, 30, 645-654. [CrossRef]

16. Price, G.D.; Twitchett, R.J.; Wheeley, J.R.; Buono, G. Isotopic evidence for long term warmth in the Mesozoic. Sci. Rep. 2013, 3, 1438. [CrossRef]

17. Veizer, J.; Prokoph, A. Temperatures and oxygen isotopic composition of Phanerozoic oceans. Earth Sci. Rev. 2015, 146, 92-104. [CrossRef]

18. Benito, M.I.; Reolid, M.; Viedma, C. On the microstructure, growth pattern and original porosity of belemnite rostra: Insights from calcitic Jurassic belemnites. J. Iber. Geol. 2016, 42, 201-226.

19. Hoffmann, R.; Richter, D.K.; Neuser, R.D.; Jöns, N.; Linzmeier, B.J.; Lemanis, R.E.; Fusseis, F.; Xiao, X.; Immenhauser, A. Evidence for a composite organic-inorganic fabric of belemnite rostra: Implications for palaeoceanography and palaeoecology. Sed. Geol. 2016, 341, 203-215. [CrossRef]

20. Benito, M.I.; Reolid, M. Comparison of the Calcareous Shells of Belemnitida and Sepiida: Is the Cuttlebone Prong an Analogue of the Belemnite Rostrum Solidum? Minerals 2020, 10, 713. [CrossRef]

21. Richter, D.K.; Neuser, R.D.; Schreuer, J.; Gies, H.; Immenhauser, A. Radial-fibrous calcites: A new look at an old problem. Sed. Geol. 2011, 239, 23-36. [CrossRef]

22. Anagnōstu, C. Sedimentpetrographische Untersuchungen im Mittleren und Oberen Dogger Süddeutschlands. Bochumer Geol. Geotech. Arbeiten 1987, 25, 1-291.

23. Linzmeier, B.J.; Kozdon, R.; Peters, S.E.; Valley, J.W. Oxygen isotope variability within Nautilus shell growth bands. PLoS ONE 2016, 11, e0153890.

24. Śliwiński, M.G.; Kitajima, K.; Kozdon, R.; Spicuzza, M.J.; Fournelle, J.H.; Denny, A.; Valley, J.W. Secondary Ion Mass Spectrometry Bias on Isotope Ratios in Dolomite-Ankerite, Part I: $\delta^{18}$ O Matrix Effects. Geostand. Geoanalytical Res. 2016, 40, 157-172. [CrossRef]

25. Kozdon, R.; Ushikubo, T.; Kita, N.T.; Spicuzza, M.; Valley, J.W. Intratest oxygen isotope variability in the planktonic foraminifer N. pachyderma: Real vs. apparent vital effects by ion microprobe. Chem. Geol. 2009, 258, 327-337. [CrossRef]

26. Pacton, M.; Breitenbach, S.F.M.; Lechleitner, F.A.; Vaks, A.; Rollion-Bard, C.; Gutareva, O.S.; Osintcev, A.V.; Vasconcelos, C. The role of microorganisms in the formation of a stalactite in Botovskaya Cave, Siberia paleoenvironmental implications. Biogeosciences 2013, 10, 6115. [CrossRef]

27. Segar, D.A.; Collins, J.D.; Riley, J.P. The Distribution of the Major and Some Minor Elements in Marine Animals Part II. Molluscs. J. Mar. Biolog. Assoc. U. K. 1971, 51, 131-136. [CrossRef]

28. Longinelli, A.; Wierzbowski, H.; Di Matteo, A. $\delta^{18} \mathrm{O}\left(\mathrm{PO}_{4}{ }^{3-}\right)$ and $\delta^{18} \mathrm{O}\left(\mathrm{CO}_{3}{ }^{2-}\right)$ from belemnite guards from Eastern Europe: Implications for palaeoceanographic reconstructions and for the preservation of pristine isotopic values. Earth Planet Sci. Lett. 2003, 209, 337-350. [CrossRef] 
29. Cuif, J.-P.; Dauphin, Y.; Berthet, P.; Jegoudez, J. Associated water and organic compounds in coral skeletons: Quantitative thermogravimetry coupled to infrared absorption spectrometry. Geochem. Geophys. Geosyst. 2004, 5, Q11011. [CrossRef]

30. Orland, I.J.; Bar-Matthews, M.; Ayalon, A.; Matthews, A.; Kozdon, R.; Ushikubo, T.; Valley, J.W. Seasonal resolution of Eastern Mediterranean climate change since $34 \mathrm{ka}$ from a Soreq Cave speleothem. Geochim. Cosmochim. Acta 2012, 89, 240-255. [CrossRef]

31. Helser, T.E.; Kastelle, C.R.; McKay, J.L.; Orland, I.J.; Kozdon, R.; Valley, J.W. Evaluation of micromilling/conventional isotope ratio mass spectrometry and secondary ion mass spectrometry of $\delta^{18} \mathrm{O}$ values in fish otoliths for sclerochronology. Rapid Commun. Mass Spectrom. 2018, 32, 1781-1790. [CrossRef]

32. Coplen, T.B. Calibration of the calcite-water oxygen-isotope geothermometer at Devils Hole, Nevada, a natural laboratory. Geochim. Cosmochim. Acta 2007, 71, 3948-3957. [CrossRef]

33. Daëron, M.; Drysdale, R.N.; Peral, M.; Huyghe, D.; Blamart, D.; Coplen, T.B.; Lartaud, F.; Zanchetta, G. Most Earth-surface calcites precipitate out of isotopic equilibrium. Nat. Comm. 2019, 10, 429. [CrossRef]

34. Geisler, T.; Perdikouri, C.; Kasioptas, A.; Dietzel, M. Real-time monitoring of the overall exchange of oxygen isotopes between aqueous and $\mathrm{H}_{2} \mathrm{O}$ by Raman spectroscopy. Geochim. Cosmochim. Acta 2012, 90, 1-11. [CrossRef]

35. Tripati, A.K.; Hill, P.S.; Eagle, R.A.; Mosenfelder, J.L.; Tang, J.; Schauble, E.A.; Eiler, J.M.; Zeebe, R.E.; Uchikawa, J.; Coplen, T.B.; et al. Beyond temperature: Clumped isotope signatures in dissolved inorganic carbon species and the influence of solution chemistry on carbonate mineral composition. Geochim. Cosmochim. Acta 2015, 166, 344-371. [CrossRef]

36. Watkins, J.M.; Hunt, J.D. A process-based model for non-equilibrium clumped isotope effects in carbonates. Earth Planet Sci. Lett. 2015, 432, 152-165. [CrossRef]

37. Watkins, J.M.; Nielsen, L.C.; Ryerson, F.J.; DePaolo, D.J. The influence of kinetics on the oxygen isotope composition of calcium carbonate. Earth Planet Sci. Lett. 2013, 375, 349-360. [CrossRef]

38. Kim, S.-T.; O'Neil, J.R. Equilibrium and nonequilibrium oxygen isotope effects in synthetic carbonates. Geochim. Cosmochim. Acta 1997, 61, 3461-3475. [CrossRef]

39. Watkins, J.M.; Hunt, J.D.; Ryerson, F.J.; DePaolo, D.J. The influence of temperature, $\mathrm{pH}$, and growth rate on the $\delta^{18} \mathrm{O}$ composition of inorganically precipitated calcite. Earth Planet Sci. Lett. 2014, 404, 332-343. [CrossRef]

40. Chen, S.; Gagnon, A.C.; Adkins, J.F. Carbonic anhydrase, coral calcification and a new model of stable isotope vital effects. Geochim. Cosmochim. Acta 2018, 236, 179-197. [CrossRef]

41. Miyamoto, H.; Miyashita, T.; Okushima, M.; Nakano, S.; Morita, T.; Matsushiro, A. A carbonic anhydrase from the nacreous layer in oyster pearls. Proc. Natl. Acad. Sci. USA 1996, 93, 9657-9660. [CrossRef]

42. McConnaughey, T.A. Sub-equilibrium oxygen-18 and carbon-13 levels in biological carbonates: Carbonate and kinetic models. Coral Reefs 2003, 22, 316-327. [CrossRef]

43. Uchikawa, J.; Zeebe, R.E. The effect of carbonic anhydrase on the kinetics and equilibrium of the oxygen isotope exchange in the $\mathrm{CO}_{2}-\mathrm{H}_{2} \mathrm{O}$ system: Implications for $\delta^{18} \mathrm{O}$ vital effects in biogenic carbonates. Geochim. Cosmochim. Acta 2012, 95, 15-34. [CrossRef]

44. Löffler, N.; Fiebig, J.; Mulch, A.; Tütken, T.; Schmidt, B.C.; Bajnai, D.; Conrad, A.C.; Wacker, U.; Böttcher, M.E. Refining the temperature dependence of the oxygen and clumped isotopic compositions of structurally bound carbonate in apatite. Geochim. Cosmochim. Acta 2019, 253, 19-38. [CrossRef]

45. McConnaughey, T.A. ${ }^{13} \mathrm{C}$ and ${ }^{18} \mathrm{O}$ isotopic disequilibrium in biological carbonates: I. Patterns. Geochim. Cosmochim. Acta 1989, 53, 151-162. [CrossRef]

46. Zeebe, R.E. An explanation of the effect of seawater carbonate concentration on foraminiferal oxygen isotopes. Geochim. Cosmochim. Acta 1999, 63, 2001-2007. [CrossRef]

47. Thébault, J.; Chauvaud, L.; Clavier, J.; Guarini, J.; Dunbar, R.B.; Fichez, R.; Mucciarone, D.A.; Morize, E. Reconstruction of seasonal temperature variability in the tropical Pacific Ocean from the shell of the scallop, Comptopallium radula. Geochim. Cosmochim. Acta 2007, 71, 918-928. [CrossRef]

48. Kennett, J.P.; Shackleton, N.J. Laurentide Ice Sheet Meltwater Recorded in Gulf of Mexico Deep-Sea Cores. Science 1975, 188, 147-150. [CrossRef] [PubMed]

49. Checa, A.G. Physical and biological determinants of the fabrication of molluscan shell microstructures. Front. Mar. Sci. 2018, 5, 353. [CrossRef]

50. Seilacher, A.; Chinzei, K. Remote biomineralization 2: Fill skeletons controlling buoyancy in shelled cephalopods. Neues Jb. Geol. Paläontol. Abh. 1993, 190, 363-373.

51. Seknazi, E.; Kozachkevich, S.; Polishchuk, I.; Bianco-Stein, N.; Villanova, J.; Suuronen, J.-P.; Dejoie, C.; Zaslansky, P.; Katsman, A.; Pokroy, B. From spinodal decomposition to alternating layered structure within single crystals of biogenic magnesium calcite. Nat. Commun. 2019, 10, 4559. [CrossRef]

52. Bianco-Stein, N.; Polishchuk, I.; Lang, A.; Atiya, G.; Villanova, J.; Zaslansky, P.; Katsman, A.; Pokroy, B. Structural and chemical variations in Mg-calcite skeletal segments of coralline red algae lead to improved crack resistance. Acta Biomater. 2021, 130, 362-373. [CrossRef] [PubMed]

53. Gutowska, M.A.; Melzner, F.; Pörtner, H.O.; Meier, S. Cuttlebone calcification increases during exposure to elevated seawater $\mathrm{pCO}_{2}$ in the cephalopod Sepia officinalis. Mar. Biol. 2010, 157, 1653-1663. [CrossRef]

54. Crick, R.E.; Ottensman, V.M. Sr, Mg, Ca and Mn chemistry of skeletal components of a Pennsylvanian and recent nautiloid. Chem. Geol. 1983, 39, 147-163. [CrossRef] 
55. Seuss, B.; Mapes, R.H.; Klug, C.; Nützel, A. Exceptional cameral deposits in a sublethally injured Carboniferous orthoconic nautiloid from the Buckhorn Asphalt Lagerstätte in Oklahoma, USA. Acta Palaeontol. Pol. 2011, 57, 375-390. [CrossRef]

56. Checa, A.G.; Macías-Sánchez, E.; Harper, E.M.; Cartwright, J.H.E. Organic membranes determine the pattern of the columnar prismatic layer of mollusc shells. Proc. R. Soc. B 2016, 283, 20160032. [CrossRef] [PubMed]

57. Bajnai, D.; Guo, W.; Spötl, C.; Coplen, T.B.; Methner, K.; Löffler, N.; Krsnik, E.; Gischler, E.; Hansen, M.; Henkel, D.; et al. Dual clumped isotope thermometry resolves kinetic biases in carbonate formation temperatures. Nat. Comm. 2020, $11,4005$. [CrossRef] [PubMed]

58. Davies, A.J.; Davis, S.; John, C.M. Evidence of taxonomic non-equilibrium effects in the clumped isotope composition of modern cephalopod carbonate. Chem. Geol. 2021, 578, 120317. [CrossRef]

59. Hoffmann, R.; Stevens, K. The palaeobiology of belemnites-Foundation for the interpretation of rostrum geochemistry. Biol. Rev. 2020, 95, 94-123. [CrossRef] [PubMed]

60. Jereb, P.; Roper, C.F.E. (Eds.) Cephalopods of the World: An Annotated and Illustrated Catalogue of Cephalopod Species Known to Date Volume 1-Chambered Nautiluses and Sepioids (Nautilidae, Sepiidae, Sepiolidae, Sepiadariidae, Idiosepiidae and Spirulidae); FAO Species Catalogue for Fishery Purposes; Food and Agriculture Organization of the United Nations-FAO: Rome, Italy, 2020; Volume 4, $262 p$. 